\title{
Superposed Late Paleozoic thermal events in the southwestern Meguma Terrane, Nova Scotia
}

\author{
R.D. Dallmeyer \\ Department of Geology, University of Georgia \\ Athens, Georgia 30602 U.S.A. \\ and \\ J.D. Keppie \\ Department of Mines and Energy, P.O. Box 1087 \\ Halifax, Nova Scotia B3J 2XI \\ Date Received December 5, 1987 \\ Date Accepted August 15, 1988
}

\begin{abstract}
Cambrian-Devonian sedimentary sequences within southwestem portions of the Meguma Terrane were deformed with attendant development of a regionally penetrative cleavage during low-grade regional metamorphism at ca.400-410 Ma. Contact aureoles developed during subsequent emplacement of the Port Mouton, Shelburne and Barrington Passage plutons at ca. 370 $375 \mathrm{Ma}$. Amphibole within calc-silicate horizons in the contact zones record internally discordant ${ }^{40} \mathrm{Ar} /{ }^{\beta 9} \mathrm{Ar}$ age spectra. However, ${ }^{36} \mathrm{Ar} /{ }^{40} \mathrm{Ar}$ vs. ${ }^{39} \mathrm{Ar} /{ }^{40} \mathrm{Ar}$ isotope correlations yield ordinate intercept values which approximate atmospheric values, and abscissa ratios corresponding to ages ranging between $385.1 \pm 2.6 \mathrm{Ma}$ and $366.9 \pm 5.6 \mathrm{Ma}$. These are interpreted to date postcontact metamorphic cooling through temperatures required for intracrystalline retention of argon. Biotite and muscovite within northem portions of the contact zones record $340-350 \mathrm{Ma}{ }^{40} \mathrm{Ar} /{ }^{39} \mathrm{Ar}$ plateau ages which date later post-metamorphic cooling through the lower temperatures required for mica argon closure. Intracrystalline argon systems within biotite and muscovite in southem portions of the contact zone of the Shelburne and Barrington Passage plutons were variably rejuvenated during a later reheating associated with emplacement of plutons at ca. $315 \mathrm{Ma}$ (Wedgeport Pluton) and $290 \mathrm{Ma}$ (offshore, subsurface pluton). Temperatures attained during these later thermal events were not sufficient to rejuvenate homblende argon systems:
\end{abstract}

Dans les portions sub-ouest de la Lanière de Méguma, les séries sédimentaires cambro-dévoniennes ont subi, il y a environ 400-410 Ma, une déformation qui s'accompagna du développement concomitant d'une schistosité pénétrative (à l'échelle régionale) au cours d'un métamorphisme régional de faible intensité. L'emplacement subséquent des plutons de Port Mouton, Shelburne et Barrington Passage se manifesta par l'implantation d'auréoles de métamorphisme vers 370-375 Ma. L'amphibole provenant de niveaux calco-silicatés, au sein des zones de contach, présente des patrons d'âge ${ }^{40} \mathrm{Ar}{ }^{9}{ }^{9} \mathrm{Ar}$ marqués par une discordance interne. En revanche, les courbes de corrélation des isotopes ${ }^{36} \mathrm{Ar} /{ }^{40} \mathrm{Ar}$ vs. ${ }^{39} \mathrm{Ar} /{ }^{40} \mathrm{Ar}$ montrent des ordonnées à l'origine se rapprochant des valeurs de l'atmosphère ainsi que des rapports en abcisse correspondant à des âges qui s'étendent de $385,1 \pm 2,6 \mathrm{Ma}$ à 366,9 $\pm 5,6 \mathrm{Ma}$. Ces âges dateraient, par le biais des températures nécessaires à la rétention intracristalline de l'argon, un refroidissement post-métamorphisme de contact. La biotite et la muscovite provenant des portions septentrionales des zones de contact ont fixé des âges limites ${ }^{40} \mathrm{Ar} / 9 \mathrm{Ar}$ de $340-350 \mathrm{Ma}$ qui datent un refroidissement post-métamorphe ultérieur à l'aide des températures plus basses régissant la fermeture de l'argon dans les micas. L'emplacement par la suite d'autres plutons aux alentours de $315 \mathrm{Ma}$ (Pluton de Wedgeport) et $290 \mathrm{Ma}$ (pluton de sous-surface en offshore) engendra la réjuvénation à divers degrés des systèmes d'argon intra-cristallin chez la biotite et la muscovite provenant des secteurs méridionaux de la zone de contact des plutons de Shelbume et Barrington Passage. Les températures atteintes lors de ces derniers épisodes thermiques restèrent en deçà de celles auxquelles fait appel la réjuvénation des systèmes d'argon de la homblende.

[Traduit par le joumal]

\section{INTRODUCTION}

The Meguma Terrane is characterized by an extensive Cambrian-Ordovician turbidite sequence which is conformably overlain by Silurian-Devonian shallow marine and continental sedimentary rocks. Following a regional, generally low-grade metamorphism (M1) and concomitant folding (D1), the metasedi- mentary sequence was intruded by numerous generally granitic plutons. Dallmeyer and Keppie (1987) presented reconnaissance ${ }^{40} \mathrm{Ar} /{ }^{39} \mathrm{Ar}$ incremental-release mineral ages (mostly for muscovite and biotite) for several granitic stocks and host metasedimentary units within southwestern portions of the Meguma Terrane. These suggested a complex late Paleozoic tectonothermal evolution which included regional $D_{1}$ folding and associated 
formation of cleavage during greenschist-lower amphibolite facies metamorphism $\left(M_{1}\right)$ at ca. $400-410$ Ma. Subsequent intrusion of granitic stocks occurred over a prolonged interval between $c a .375$ and $285 \mathrm{Ma}$. The plutons were emplaced at shallow to intermediate crustal depths and developed contact metamorphic aureoles of variable size and grade. These overprinted $M_{1}$ regional metamorphic assemblages and are locally mutually superposed. The regional extent and relative intensities of individual thermal events affecting southwestern portions of the Meguma Terrane were not clearly defined by the reconnaisance mica ages reported by Dallmeyer and Keppie (1988). In an attempt to more clearly resolve thermal overprinting relationships, samples of amphibole-bearing, calc-silicate horizons were collected within the southwestem Meguma Terrane for ${ }^{40} \mathrm{Ar} /{ }^{39} \mathrm{Ar}$ analysis. These results are presented here and when combined with U-Pb ages reported by Keppie and Krogh (1987) for crystallization of zircon within two large plutons in the area (Shelburne and Barrington Passage plutons) allow a much clearer resolution of the regional tectonothermal evolution than was previously possible.

\section{REGIONAL GEOLOGIC SETTING}

The Meguma Group and overlying Silurian-Devonian formations were deformed into upright, subhorizontal $D_{1}$ folds which display a variably developed, axial planar, spaced cleavage. In pelitic horizons the cleavage is generally penetrative, and defined, in part, by the preferred orientation of chlorite, muscovite and/or biotite (Taylor and Schiller, 1966; Keppie, 1976). This suggests that a regional low-grade metamorphism $\left(M_{1}\right)$ accompanied $D_{1}$ deformation. Numerous plutons cross-cut $D_{1}$ fabric elements. These are predominantly granodiorite and granite with subordinate quartz diorite and alaskite porphyry.
The plutons typically are surrounded by low-pressure contact metamorphic aureoles characterized by development of porphyroblastic chlorite, biotite, cordierite, staurolite, andalusite and/or sillimanite (Taylor and Schiller, 1966; Keppie and Meucke, 1979) which typically overgrow $D_{1}$ fabric elements (Sage, 1984; Keppie et al., 1985). This contact metamorphism is widespread in southwestem Nova Scotia (Fig. 1) and was initially interpreted as a regional metamorphic event (e.g., Taylor and Schiller, 1966). However, recent detailed mapping (Sage, 1984; White, 1984; Bourque, 1985; Ross, 1985; Wentzell, 1985; Keppie et al., 1985; Raeside et al., 1985; Misner, 1986) suggests that the isograds are spatially related to exposed pluton contacts. Superposition of contact aureoles locally has produced complex textural relationships and zoned porphyroblasts; however, no maps presently exist showing these intersecting isograds. Therefore, the isograds shown in Figures 1 and 2 reflect cumulative peak metamorphic assemblages. Detailed mapping of the isograds throughout poorly exposed interior portions of the Meguma Terrane has not been attempted. In these areas only the reconnaissance isograds defined by Keppie and Muecke (1979) are available.

Variably penetrative ductile shear zones are locally developed throughout the Meguma Terrane. These affect both granitic plutons and host metasedimentary units. The shear zones generally dip steeply and trend parallel to regional strike. Preliminary analysis of associated fabric elements suggests that most formed during dextral shear (Keppie et al., 1985). While a portion of this strain occurred in the late Devonian (Dallmeyer and Keppie, 1987), some is also recorded in the $315 \pm 3 \mathrm{Ma}$ Wedgeport pluton (Keppie et al., 1983). In places the ductile shear zone fabrics are overgrown by undeformed contact metamorphic porphyroblasts of muscovite and/or biotite while elsewhere micas are dynamically recrystallized.

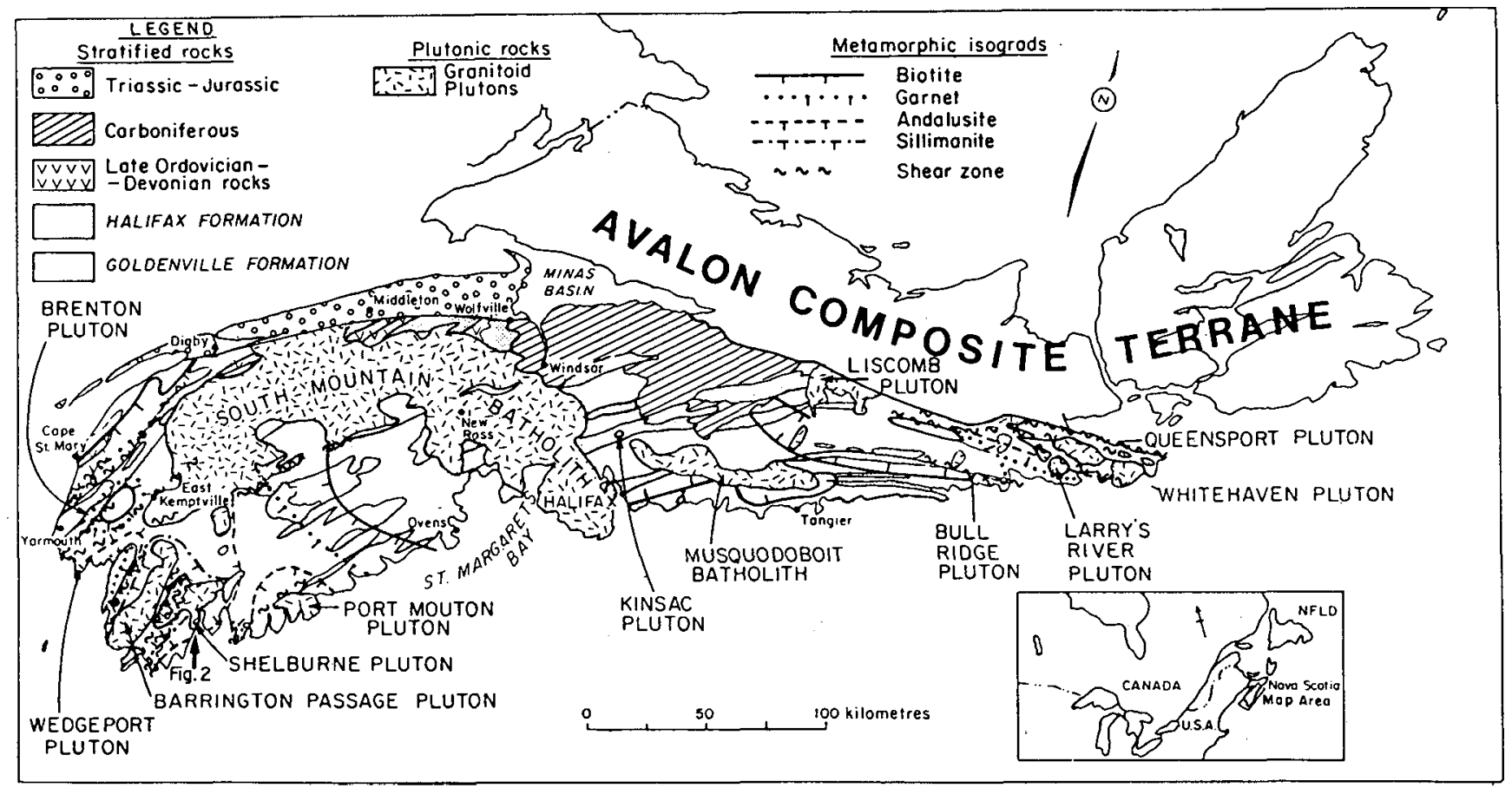

Fig. 1. Simplified geological map of the Meguma Terrane, Nova Scotia. Area of Figure 2 is outlined. Tick-marks on high-grade side of isograds. Individual plutons are named. Area of Figure 2 is indicated. 


\section{PREVIOUS GEOCHRONOLOGY}

Isotopic ages previously reported for the Meguma Terrane have been summarized by Dallmeyer and Keppie (1987). In addition, Keppie and Krogh (1988) reported ca. 370-375 Ma U-
$\mathrm{Pb}$ zircon crystallization ages for the Shelburne and Barrington Passage plutons. The ${ }^{40} \mathrm{Ar} /{ }^{\beta 9} \mathrm{Ar}$ mineral ages presented by Dallmeyer and Keppie (1987) from the present study area are located in Figure 2.

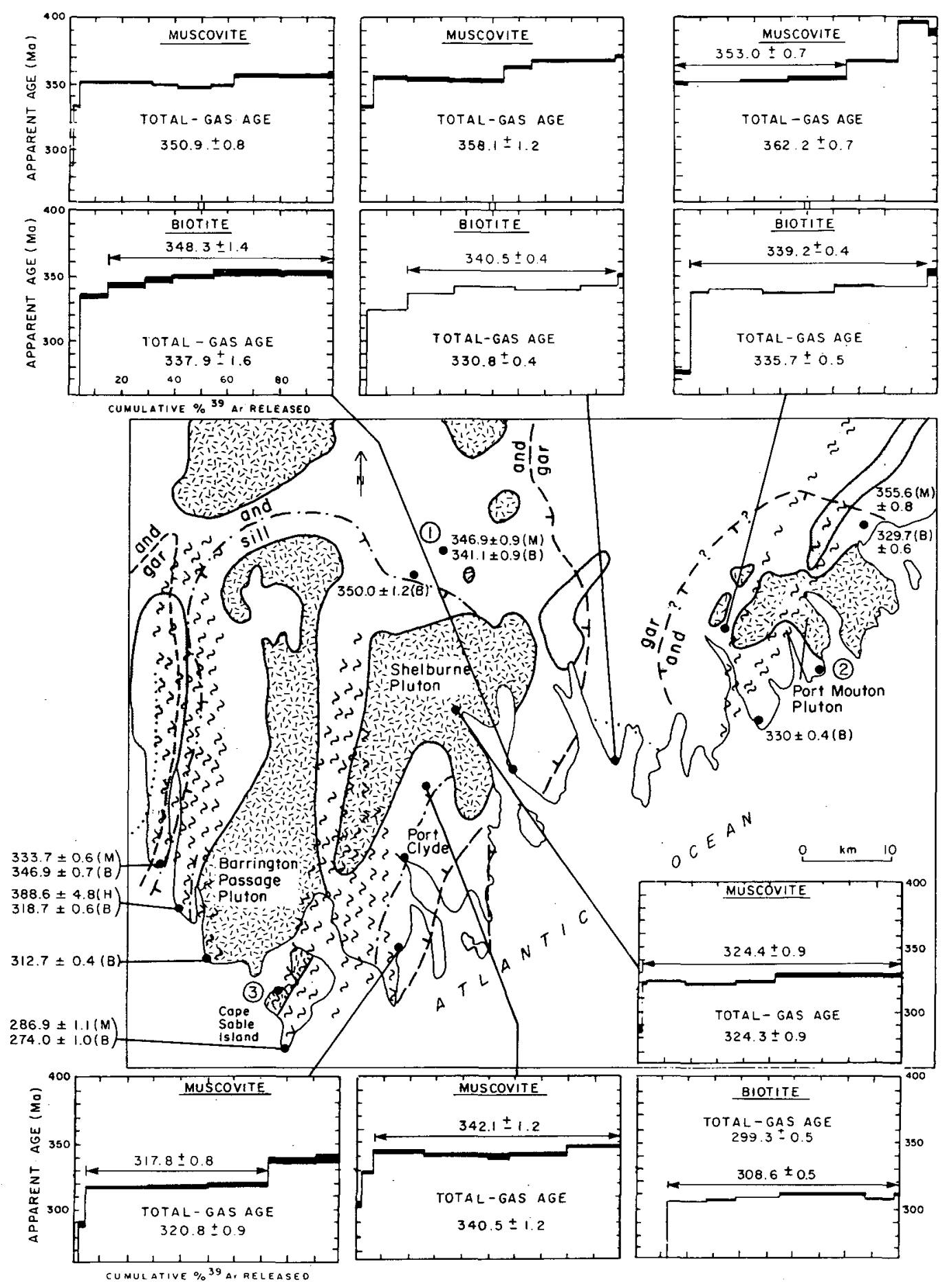

Fig. 2. Location of the three exposures (circled numbers) investigated in this study (refer to Fig. 1 for area and map explanation) compared with the ${ }^{40} \mathrm{Ar} /{ }^{\beta 9} \mathrm{Ar}$ mineral ages presented by Dallmeyer and Keppie (1987): plateau ages shown for hornblende (H), biotite (B), and/or muscovite (M) concentrates recording internally concordant age spectra; all discordant spectra are shown (abscissa and ordinate coordinates similar for all samples). Analytical uncertainties (two sigma, intralaboratory) are represented by vertical width of bars. Experimental temperatures increase from left to right. Plateau and/or total-gas ages listed on each spectrum. Isograd ornamentation identical to that in Figure 1 (gar = garnet, and = andalusite, sill = sillimanite). Shear zones are indicated. 


\section{ANALYTICAL METHODS}

${ }^{40} \mathrm{Ar} /{ }^{39} \mathrm{Ar}$

The techniques used during ${ }^{40} \mathrm{Ar} /{ }^{\beta 9} \mathrm{Ar}$ analyses of the Meguma samples generally followed those described in detail by Dallmeyer and Keppie (1987). The mineral concentrates were wrapped in aluminum-foil packets, encapsulated in sealed quartz vials, and irradiated for $40 \mathrm{hr}$ at $1000 \mathrm{Kw}$ in the central thimble position of the U.S. Geological Survey TRIGA reactor in Denver, Colorado. Variations in the flux of neutrons along the length of the irradiation assembly were monitored with several mineral standards, including MMhb-1 (Alexander et al., 1978). The samples were incrementally heated until fusion with an RF generator. Each heating step was maintained for 30 minutes. Operational system blanks were routinely measured. Although these were consistently characterized by an atmospheric argon isotopic composition, blank volumes were variable (0.8-6.2 $\times 10$. ${ }^{12} \mathrm{STP} \mathrm{cm}^{3} \mathrm{for}^{36} \mathrm{Ar}$ ) and demonstrated a complex dependence on: (1) crucible temperature; (2) history of the furnace following sample loading; and (3) samples characteristics (weight, material, grain size, density). In view of this uncertainty and because blanks generally represented less than $c a .5 \%$ of the total measured ${ }^{40} \mathrm{Ar}$ signal, blank corrections have not been applied to the analytical data. Measured isotopic ratios were corrected for the effects of mass discrimination and interfering isotopes produced during irradiation using factors reported by Dalrymple $e t$ al. (1981) for the reactor used in the present study. Apparent ${ }^{40} \mathrm{Ar} /$ ${ }^{39} \mathrm{Ar}$ ages were calculated from the corrected isotopic ratios using the decay constants and isotopic abundance ratios listed by Steiger and Jäger (1977).

Two categories of uncertainties are encountered in ${ }^{40} \mathrm{Ar} /{ }^{39} \mathrm{Ar}$ incremental-release dating. One group involves intralaboratory uncertainties related to measurement of the isotopic ratios used in the age equation. The other group considers interlaboratory uncertainties in the other parameters used in the age equation (monitor age, J-value determination, etc.), and are the same for each gas increment evolved from a particular sample. Therefore, to evaluate the significance of potential incremental age variations within a sample, only intralaboratory uncertainties should be considered. These are reported here for the incremental gas ages. They have been calculated by statistical propagation of uncertainties associated with measurement of each isotopic ratio (at two standard deviations of the mean) through the age equation. Intralaboratory uncertainties are $c a . \pm 1.25-1.5 \%$ of the quoted age. Total-gas ages have been computed for each sample by appropriated weighting of the age and percent ${ }^{39} \mathrm{Ar}$ released within each temperature increment. Analyses of the MMhb-1 monitor indicate that apparent $\mathrm{K} / \mathrm{Ca}$ ratios may be calculated through the relationship $0.518( \pm 0.0005) \times 3^{9} \mathrm{Ar}{ }^{\beta 7} \mathrm{Ar}$ corrected.

The analyses of the amphibole concentrates have been plotted on ${ }^{36} \mathrm{Ar}{ }^{\mu 0} \mathrm{Ar}$ vs. ${ }^{39} \mathrm{Ar} /{ }^{\mu 0} \mathrm{Ar}$ isotope correlation diagrams (Roddick et al., 1980; Radicati de Brozolo et al., 1981). Regression techniques followed the methods of York (1969). The mean square of the weighted deviates (MSWD) has been used to evaluate isotopic correlations. Roddick (1978) suggests that an MSWD in excess of $c a .2 .5$ indicates scatter about a correlation line greater than that which can be explained only by experimental errors.

\section{Electron microprobe}

The techniques used during electron microprobe analyses of the amphibole concentrates generally followed those described in detail by Cho (1985). Grains were analyzed in carbon-coated, polished epoxy mounts with a JEOL JCXA-733 electron microprobe using an accelerating potential of $15 \mathrm{kV}$ and a beam current of $1 \times 10^{-8} \mathrm{amp}$ (on faraday cage). Na-Fe-K, Si-Mn-Ca, Al-Ti, or $\mathrm{Mg}$ were analyzed simultaneously. Ten five-second integrations were performed for each spot analyzed. A $10 \mu \mathrm{m}$ beam diameter was maintained. Following dead-time corrections, oxide percentages were calculated using a modification of the BenceAlbee method (JEOL program).

\section{RESULTS}

Samples of calc-silicate (A) and interlayered metapelitic schist (B) were collected at three locations (1-3) within the Goldenville Formation adjacent to exposed plutons in the southwestern Meguma Terrane. Sample locations are indicated in Figure 2. Locations 1 and 2 occur within the andalusite-staurolite-cordierite metamorphic zone whereas location 3 is situated in the sillimanite zone. Concentrates of amphibole, muscovite, and/ or biotite have been analyzed from these samples. The analytical data are listed in Tables 2 and 3 , and are portrayed as incrementalrelease age spectra in Figures 3 and 5. Dallmeyer and Keppie (1987) reported ${ }^{40} \mathrm{Ar}{ }^{\beta 9} \mathrm{Ar}$ ages for concentrates of muscovite and biotite from schist interlayered with calc-silicate at location 1 (numbered 15 on their Fig. 3).

\section{Amphibole}

The calc-silicate horizons occur as thin $(<0.5 \mathrm{~m})$, discontinuous, elliptical lithologic intervals with granoblastic textures. They are composed predominantly of amphibole, plagioclase and quartz with subordinate garnet. The amphibole crystals display no petrographic evidence of exsolution or zoning. Electron microprobe analyses of representative constituent grains within the concentrates prepared for ${ }^{40} \mathrm{Ar} /{ }^{\beta 9} \mathrm{Ar}$ analysis (Table 1) indicate that the concentrates are compositionally uniform. Following the classifications of Leake (1978) and Hawthome (1982), those from samples $1 \mathrm{~A}$ and $2 \mathrm{~A}$ range between ferrohornblende and ferro-actinolitic hornblende. The concentrate from sample $3 \mathrm{~A}$ is slightly more magnesian, with compositions ranging between magnesio-homblende and actinolitic hornblende.

The amphibole concentrate from sample 1A displays an internally discordant ${ }^{40} \mathrm{Ar} /{ }^{9} \mathrm{Ar}$ age spectrum corresponding to a total-gas age of $392.6 \pm 4.5 \mathrm{Ma}$ (Fig. 3). The apparent K/Ca spectrum shows little variation suggesting that the concentrate is characterized by relatively homogenous grains. The remaining 11 increments $\left(625-925^{\circ} \mathrm{C}\right)$ constitute $c a .94 \%$ of the total gas evolved from the concentrate and generally contain $>60 \%$ radiogenic ${ }^{40} \mathrm{Ar}$. These increments define $\mathrm{a}^{36} \mathrm{Ar} /{ }^{40} \mathrm{Ar}$ vs. ${ }^{39} \mathrm{Ar} /{ }^{40} \mathrm{Ar}$ correlation line (MSWD $=2.9)$ with intercepts corresponding to 
Table 1. Representative electron microprobe analyses of constituent grains within amphibole concentrates from calc-silicate horizons in the Goldenville Formation, southwestern Meguma Terrane.

\begin{tabular}{|c|c|c|c|c|c|c|c|c|c|}
\hline & \multicolumn{9}{|c|}{ Sample 1A } \\
\hline & \multicolumn{3}{|c|}{ GRAIN 1} & \multicolumn{3}{|c|}{ GRAIN 2} & \multicolumn{3}{|c|}{ GRAIN 3} \\
\hline & $1^{+}$ & 2 & 3 & 1 & 2 & 3 & 1 & 2 & 3 \\
\hline $\mathrm{SiO}_{2}$ & 49.60 & 49.31 & 48.82 & 50.24 & 47.22 & 46.73 & 46.41 & 46.33 & 44.39 \\
\hline $\mathrm{TiO}_{2}$ & 0.20 & 0.25 & 0.27 & 0.18 & 0.47 & 0.40 & 0.49 & 0.28 & 0.42 \\
\hline $\mathrm{Al}_{2} \mathrm{O}_{3}$ & 4.98 & 5.24 & 5.86 & 4.62 & 8.78 & 8.90 & 9.82 & 10.01 & 12.54 \\
\hline $\mathrm{FeO}^{*}$ & 19.38 & 19.70 & 19.72 & 18.59 & 19.01 & 19.84 & 17.98 & 18.38 & 18.69 \\
\hline $\mathrm{MnO}$ & 0.65 & 0.60 & 0.59 & 0.61 & 0.56 & 0.53 & 0.45 & 0.62 & 0.47 \\
\hline $\mathrm{MgO}$ & 9.96 & 10.13 & 9.34 & 10.77 & 8.93 & 8.92 & 9.37 & 9.34 & 8.06 \\
\hline $\mathrm{CaO}$ & 12.35 & 11.75 & 12.06 & 12.09 & 11.97 & 11.99 & 12.03 & 11.84 & 11.80 \\
\hline $\mathrm{Na}_{2} \mathrm{O}$ & 0.24 & 0.28 & 0.27 & 0.20 & 0.48 & 0.42 & 0.53 & 0.65 & 0.63 \\
\hline $\mathrm{K}_{2} \mathrm{O}$ & 0.06 & 0.07 & 0.04 & 0.05 & 0.09 & 0.11 & 0.07 & 0.09 & 0.17 \\
\hline Total & 97.42 & 97.33 & 96.97 & 97.35 & 97.51 & 97.84 & 97.15 & 97.54 & 97.17 \\
\hline \multicolumn{10}{|c|}{ Numbers of Ions on the Basis of $23(0)$} \\
\hline $\mathrm{Si}$ & 7.436 & 7.400 & 7.361 & 7.493 & 7.066 & 7.004 & 6.942 & 6.921 & 6.673 \\
\hline $\mathrm{Al}^{\mathrm{IV}}$ & 0.564 & 0.600 & 0.639 & 0.507 & 0.934 & 0.996 & 1.058 & 1.079 & 1.327 \\
\hline $\begin{array}{l}\mathrm{Al}^{\mathrm{VI}} \\
\mathrm{Ti}\end{array}$ & 0.316 & $\begin{array}{l}0.327 \\
0.028\end{array}$ & $\begin{array}{l}0.403 \\
0.031\end{array}$ & $\begin{array}{l}0.305 \\
0.020\end{array}$ & 0.615 & $\begin{array}{l}0.576 \\
0.045\end{array}$ & $\begin{array}{l}0.673 \\
0.055\end{array}$ & $\begin{array}{l}0.683 \\
0.031\end{array}$ & $\begin{array}{l}0.895 \\
0.047\end{array}$ \\
\hline $\mathrm{Fe}^{+2}$ & 2.430 & 2.473 & 2.487 & 2.319 & 2.379 & 2.487 & 2.249 & 2.296 & 2.350 \\
\hline $\mathrm{Mn}$ & 0.083 & 0.076 & 0.075 & 0.077 & 0.071 & 0.067 & 0.057 & 0.078 & 0.060 \\
\hline $\mathrm{Mg}$ & 2.226 & 2.266 & 2.099 & 2.394 & 1.992 & 1.993 & 2.089 & 2.080 & 1.806 \\
\hline XM 1-3 & 0.078 & 0.170 & 0.095 & 0.115 & 0.110 & 0.168 & 0.123 & 0.168 & 0.158 \\
\hline $\mathrm{Ca}$ & 1.984 & 1.890 & 1.949 & 1.932 & 1.919 & 1.926 & 1.928 & 1.895 & 1.901 \\
\hline & 2.062 & 2.060 & 2.044 & 2.047 & 2.029 & 2.094 & 2.051 & 2.063 & 2.059 \\
\hline $\begin{array}{l}N \\
K\end{array}$ & 0.070 & 0.081 & 0.079 & 0.058 & 0.139 & 0.122 & 0.154 & 0.188 & 0.184 \\
\hline $\mathrm{K}$ & 0.011 & 0.013 & 0.008 & 0.010 & 0.017 & 0.021 & 0.013 & 0.017 & 0.033 \\
\hline & 0.081 & 0.094 & 0.087 & 0.068 & 0.156 & 0.143 & 0.167 & 0.205 & 0.217 \\
\hline $\mathrm{Mg} / \mathrm{Fe}^{*}+\mathrm{Mg}$ & 0.443 & 0.435 & 0.446 & 0.434 & 0.464 & 0.467 & 0.473 & 0.471 & 0.495 \\
\hline
\end{tabular}

Sample 2A

GRAIN 1

\begin{tabular}{rrr}
\hline 1 & \multicolumn{1}{c}{2} & 3 \\
50.25 & 48.66 & 45.03 \\
0.13 & 0.14 & 0.36 \\
4.34 & 5.79 & 9.93 \\
18.18 & 19.82 & 19.98 \\
0.68 & 0.80 & 0.64 \\
11.13 & 9.46 & 8.23 \\
12.26 & 12.12 & 12.37
\end{tabular}

GRAIN 2

\begin{tabular}{|c|c|c|c|c|c|}
\hline 1 & 2 & 3 & 1 & 2 & 3 \\
\hline 49.10 & 48.85 & 46.76 & 46.70 & 45.97 & 45.54 \\
\hline 0.20 & 0.17 & 0.32 & 0.23 & 0.30 & 0.28 \\
\hline 4.75 & 6.12 & 8.16 & 8.23 & 8.35 & 8.76 \\
\hline 19.87 & 19.54 & 20.73 & 21.15 & 22.32 & 21.98 \\
\hline 0.68 & 0.55 & 0.59 & 0.45 & 0.63 & 0.58 \\
\hline 10.31 & 9.87 & 8.46 & 8.20 & 7.40 & 7.52 \\
\hline 12.15 & 12.09 & 12.07 & 11.75 & 11.93 & 11.94 \\
\hline
\end{tabular}


Table 1. Representative electron microprobe analyses of constituent grains within amphibole concentrates from calc-silicate horizons in the Goldenville Formation, southwestern Meguma Terrane.

\begin{tabular}{|c|c|c|c|c|c|c|c|c|c|}
\hline $\mathrm{Na}_{2} \mathrm{O}$ & 0.26 & 0.32 & 0.59 & 0.33 & 0.35 & 0.49 & 0.44 & 0.43 & 0.58 \\
\hline $\mathrm{K}_{2} \mathrm{O}$ & 0.03 & 0.04 & 0.11 & 0.02 & 0.06 & 0.08 & 0.08 & 0.07 & 0.08 \\
\hline Total & 97.26 & 97.15 & 97.24 & 97.41 & 97.60 & 97.66 & 97.23 & 97.40 & 97.26 \\
\hline \multicolumn{10}{|c|}{ Numbers of Ions on the Basis of 23(0) } \\
\hline $\mathrm{Si}$ & 7.498 & 7.342 & 6.833 & 7.390 & 7.313 & 7.060 & 7.082 & 1.019 & 6.961 \\
\hline $\mathrm{Al}^{\mathrm{IV}}$ & 0.502 & 0.658 & 1.167 & 0.610 & 0.687 & 0.940 & 0.918 & 0.981 & 1.039 \\
\hline $\begin{array}{l}\mathrm{Al} V I \\
\mathrm{Ti}^{2}\end{array}$ & 0.261 & 0.372 & 0.609 & 0.233 & 0.393 & 0.512 & 0.553 & 0.522 & $\begin{array}{l}0.539 \\
0.032\end{array}$ \\
\hline $\begin{array}{l}\mathrm{Ti} \\
\mathrm{Fe}^{+2}\end{array}$ & $\begin{array}{l}0.015 \\
2.269\end{array}$ & $\begin{array}{l}0.016 \\
2.501\end{array}$ & $\begin{array}{l}0.041 \\
2.536\end{array}$ & $\begin{array}{l}0.023 \\
2.501\end{array}$ & $\begin{array}{l}0.019 \\
2.447\end{array}$ & $\begin{array}{l}0.036 \\
2.618\end{array}$ & $\begin{array}{l}0.026 \\
2.683\end{array}$ & $\begin{array}{l}0.034 \\
2.850\end{array}$ & $\begin{array}{l}0.032 \\
2.810\end{array}$ \\
\hline $\mathrm{Mn}$ & 0.086 & 0.102 & 0.082 & 0.087 & 0.070 & 0.075 & 0.058 & 0.081 & 0.075 \\
\hline $\mathrm{Mg}$ & 2.476 & 2.128 & 1.862 & 2.313 & 2.203 & 1.904 & 1.854 & 1.684 & 1.713 \\
\hline XM 1-3 & 0.107 & 0.119 & 0.130 & 0.157 & 0.132 & 0.145 & 0.174 & 0.171 & 0.169 \\
\hline \multirow{2}{*}{$\mathrm{Ca}$} & 1.960 & 1.959 & 2.011 & 1.959 & 1.939 & 1.953 & 1.909 & 1.952 & 1.955 \\
\hline & 2.067 & 2.078 & 2.141 & 2.116 & 2.071 & 2.098 & 2.083 & 2.123 & 2.124 \\
\hline $\mathrm{N}$ & 0.075 & 0.094 & 0.174 & 0.096 & 0.102 & 0.143 & 0.129 & 0.127 & 0.172 \\
\hline \multirow{2}{*}{$\mathrm{K}$} & 0.006 & 0.008 & 0.021 & 0.004 & 0.011 & 0.015 & 0.015 & 0.014 & 0.016 \\
\hline & 0.081 & 0.102 & 0.195 & 0.100 & 0.113 & 0.158 & 0.144 & 0.141 & 0.188 \\
\hline $\mathrm{Mg} / \mathrm{Fe}^{*}+\mathrm{Mg}$ & 0.522 & 0.460 & 0.423 & 0.480 & 0.474 & 0.421 & 0.409 & 0.371 & 0.379 \\
\hline
\end{tabular}

Sample 3A

GRAIN 1

\begin{tabular}{lll}
\hline 1 & 2 & 3
\end{tabular}

$\begin{array}{lrrr}\mathrm{SiO}_{2} & 46.41 & 46.10 & 46.11 \\ \mathrm{TiO}_{2} & 0.63 & 0.62 & 0.67 \\ \mathrm{Al}_{2} \mathrm{O}_{3} & 9.63 & 9.30 & 9.79 \\ \mathrm{FeO}^{*} & 15.50 & 15.38 & 15.80 \\ \mathrm{MnO} & 0.93 & 1.25 & 0.91 \\ \mathrm{MgO} & 11.55 & 11.95 & 11.40 \\ \mathrm{CaO} & 11.31 & 11.36 & 11.31 \\ \mathrm{Na} 2 \mathrm{O} & 1.05 & 1.18 & 1.05 \\ \mathrm{~K}_{2} \mathrm{O} & 0.24 & 0.18 & 0.21 \\ & & & \\ & 97.25 & 97.32 & 97.25\end{array}$

Total

$\mathrm{Si}$
$\mathrm{Al}^{\mathrm{IV}}$
$\mathrm{Al} \mathrm{VI}$
$\mathrm{Ti}$
$\mathrm{Fe}^{+2}$
$\mathrm{Mn}$
$\mathrm{Mg}$

GRAIN 2

\begin{tabular}{lll}
\hline 1 & 2 & 3
\end{tabular}

44.34

$\begin{array}{rr}44.15 & 43.46 \\ 0.61 & 0.53 \\ 12.41 & 12.27 \\ 18.09 & 18.26 \\ 0.42 & 0.52 \\ 8.64 & 8.69 \\ 11.44 & 11.85 \\ 1.25 & 1.41 \\ 0.33 & 0.27\end{array}$

$97.34 \quad 97.26$

12.19

17.70

0.37

9.11

11.35

1.24

0.61

97.50

Numbers of Ions on the Basis of 23(0)

$\begin{array}{lllllllll}6.884 & 6.852 & 6.852 & 6.641 & 6.628 & 6.563 & 6.590 & 6.537 & 6.260 \\ 1.116 & 1.148 & 1.148 & 1.359 & 1.372 & 1.437 & 1.410 & 1.463 & 1.740 \\ & & & & & & & & \\ 0.568 & 0.481 & 0.567 & 0.793 & 0.824 & 0.747 & 0.706 & 0.601 & 0.868 \\ 0.070 & 0.069 & 0.075 & 0.066 & 0.069 & 0.060 & 0.077 & 0.080 & 0.055 \\ 1.923 & 1.912 & 1.963 & 2.217 & 2.271 & 2.306 & 2.485 & 2.535 & 2.677 \\ 0.117 & 0.157 & 0.115 & 0.047 & 0.053 & 0.067 & 0.021 & 0.081 & 0.072 \\ 2.554 & 2.648 & 2.525 & 2.034 & 1.934 & 1.956 & 1.854 & 1.838 & 1.494\end{array}$

GRAIN 3

\begin{tabular}{rrr}
\hline & \multicolumn{1}{c}{2} & \multicolumn{1}{c}{3} \\
43.24 & 42.83 & 40.74 \\
0.67 & 0.70 & 0.48 \\
11.78 & 11.47 & 14.40 \\
19.50 & 19.86 & 20.83 \\
0.16 & 0.63 & 0.55 \\
8.16 & 8.08 & 6.52 \\
11.74 & 12.17 & 11.93 \\
1.24 & 1.25 & 1.43 \\
0.33 & 0.40 & 0.37 \\
& & \\
96.82 & 97.39 & 97.25
\end{tabular}


Table 1. Representative electron microprobe analyses of constituent grains within amphibole concentrates from calc-silicate horizons in the Goldenville Formation, southwestern Meguma Terrane.

\begin{tabular}{llllllllll}
\hline $\mathrm{XM} 1-3$ & 0.232 & 0.267 & 0.245 & 0.157 & 0.151 & 0.136 & 0.143 & 0.135 & 0.166 \\
$\mathrm{Ca}$ & 1.798 & 1.809 & 1.801 & 1.821 & 1.840 & 1.917 & 1.917 & 1.990 & 1.964 \\
& 2.030 & 2.076 & 2.046 & 1.978 & 1.991 & 2.053 & 2.060 & 2.125 & 2.130 \\
$\mathrm{~N}$ & & & & & & & & & \\
$\mathrm{~K}$ & 0.302 & 0.340 & 0.303 & 0.360 & 0.364 & 0.413 & 0.366 & 0.370 & 0.426 \\
& 0.045 & 0.034 & 0.040 & 0.117 & 0.063 & 0.052 & 0.064 & 0.078 & 0.073 \\
$\mathrm{Mg} / \mathrm{Fe}{ }^{*}+\mathrm{Mg}$ & 0.347 & 0.374 & 0.343 & 0.477 & 0.427 & 0.465 & 0.430 & 0.448 & 0.499 \\
\hline
\end{tabular}

+ spot 1,2 , and 3

* Fe as total $\mathrm{FeO}$

an age of $385.1 \pm 2.6 \mathrm{Ma}$ and $\mathrm{a}^{40} \mathrm{Ar} /{ }^{36} \mathrm{Ar}$ ratio of $295.7 \pm 6.3$ (Fig. 4).

The amphibole concentrate prepared from sample $2 \mathrm{~A}$ records an internally discordant ${ }^{40} \mathrm{Ar} /{ }^{9} \mathrm{Ar}$ age spectrum with a totalgas age of $381.6 \pm 6.6 \mathrm{Ma}$ (Fig. 3). Apparent $\mathrm{K} / \mathrm{Ca}$ ratios are variable in the four low-temperature increments $\left(550-650^{\circ} \mathrm{C}\right)$ whereas the remaining 12 increments $\left(700^{\circ} \mathrm{C}\right.$-fusion) record constant ratios. These increments are therefore interpreted to represent gas evolved from a chemically homogeneous mineral phase. Each of the 8 increments evolved between 700 and $815^{\circ} \mathrm{C}$ contains $>60 \%$ non-atmospheric ${ }^{40} \mathrm{Ar}$ components. These increments define $\mathrm{a}^{36} \mathrm{Ar} /{ }^{\mu 0} \mathrm{Ar}$ vs. ${ }^{39} \mathrm{Ar} /{ }^{\mu 0} \mathrm{Ar}$ correlation line (MSWD $=$ 3.2) yielding intercepts corresponding to a ${ }^{40} \mathrm{Ar} /{ }^{36} \mathrm{Ar}$ ratio of $307.5 \pm 10.4$ and an age of $369.1 \pm 2.9 \mathrm{Ma}$.

An internally discordant age spectrum is also displayed by the amphibole concentrate prepared from sample 3A (Fig. 3). A total-gas age of $376.5 \pm 5.2 \mathrm{Ma}$ is defined. The five low-temperature increments $\left(500-700^{\circ} \mathrm{C}\right)$ record variable apparent $\mathrm{K} / \mathrm{Ca}$ ratios. The remaining 10 increments $\left(720^{\circ} \mathrm{C}\right.$-fusion) are characterized by a $\mathrm{K} / \mathrm{Ca}$ ratio of $\mathrm{c}$. 0.050 , suggesting experimental evolution of gas from a chemically homogeneous phase. Each of the increments evolved between 720 and $845^{\circ} \mathrm{C}$ contains $>80 \%$ non-atmospheric ${ }^{40} \mathrm{Ar}$. These define a ${ }^{36} \mathrm{Ar} /{ }^{40} \mathrm{Ar}$ vs. ${ }^{39} \mathrm{Ar} /{ }^{40} \mathrm{Ar}$ correlation line (MSWD $=4.7$ ) with intercepts corresponding to $\mathrm{a}^{40} \mathrm{Ar} /{ }^{6} \mathrm{Ar}$ ratio of $319.1 \pm 9.8$ and an age of $366.9 \pm 5.6 \mathrm{Ma}$.

\section{Biotite and muscovite}

Dallmeyer and Keppie (1987) previously reported ${ }^{40} \mathrm{Ar} /{ }^{9} \mathrm{Ar}$ plateau ages of $341.1 \pm 0.9 \mathrm{Ma}$ and $346.9 \pm 0.9 \mathrm{Ma}$ for biotite and muscovite within schist from the exposure where calc-silicate sample 1A was collected (location 15 in Fig. 3 of Dallmeyer and Keppie, 1987). A muscovite concentrate has been prepared from schist at location 2 . This displays an internally concordant ${ }^{40} \mathrm{Ar} /$ ${ }^{39} \mathrm{Ar}$ age spectrum corresponding to a plateau age of $346.6 \pm 0.9$ $\mathrm{Ma}$ (Table 3, Fig. 5). Apparent $\mathrm{K} / \mathrm{Ca}$ ratios are very large and display no significant or systematic variations throughout the analysis. Biotite and muscovite concentrates were also prepared from schist at location 3 (Fig. 6). These display minor spectra discordance with slightly younger ages recorded in the lowest temperature increments; however, plateau ages of $285.4 \pm 0.7 \mathrm{Ma}$ (biotite) and $309.9 \pm 0.8 \mathrm{Ma}$ (muscovite) are defined by $>90 \%$ of the total gas evolved from each sample (Fig. 5). Apparent K/Ca ratios are very large and display no significant or systematic variations in either analysis.

\section{INTERPRETATION}

The three amphibole concentrates record variably discordant ${ }^{40} \mathrm{Ar} /{ }^{\beta} \mathrm{Ar}$ age spectra. The larger volume increments within those portions of each analysis characterized by internally consistent $\mathrm{K} / \mathrm{Ca}$ ratios yield ${ }^{36} \mathrm{Ar} /{ }^{\mu 0} \mathrm{Ar}$ vs. ${ }^{39} \mathrm{Ar}{ }^{\mu 0} \mathrm{Ar}$ correlation lines defining ordinate intercepts corresponding to an atmospheric ${ }^{40} \mathrm{Ar} /{ }^{36} \mathrm{Ar}$ ratio. Abcissa intercepts yield ${ }^{40} \mathrm{Ar} /{ }^{9} \mathrm{Ar}$ ratios corresponding to ages which range between $366.9 \pm 5.6 \mathrm{Ma}$ and $385.1 \pm 2.6 \mathrm{Ma}$. These are interpreted to date the last cooling through temperatures required for intra-crystalline retention of argon. Harrison (1981) suggested that argon retention occurs at ca. $500 \pm 25^{\circ} \mathrm{C}$ in hornblende at the cooling rates likely to be encountered in most geologic settings. It is uncertain if similar temperatures characterize the amphibole compositions examined in the present study .

Lack of internal variations in apparent $\mathrm{K} / \mathrm{Ca}$ ratios indicate that the biotite and muscovite concentrates are homogeneous and characterized by chemically uniform grains. The concentrates record plateau ages ranging between $285.4 \pm 0.7 \mathrm{Ma}$ and $346.6 \pm 0.9$ $\mathrm{Ma}$. These are interpreted to date the last cooling through argon retention temperatures. Harrison et al. (1985) have demonstrated that the temperatures required for intracrystalline retention of argon in biotite are dependent upon composition and increase with decreasing $\mathrm{Fe} / \mathrm{Mg}$ ratio. They suggest that closure occurs at ca. $300 \pm 25^{\circ} \mathrm{C}$ in the range of cooling rates likely to be encountered in most geologic environments. Detailed experimental evaluation of the temperatures required for intracrystalline retention of argon in muscovite have not been carried out. Using the preliminary experimental data of Robbins (1972) in the diffusion equations of Dodson (1973) suggests that temperatures of $c a$. $350^{\circ} \mathrm{C}$ may be appropriate. These are similar to closure temperatures suggested for muscovite on the basis of empircal comparison with argon systems within other mineral species (e.g., Wagner et al., 1977; Jäger, 1979). 
Table 2. ${ }^{40} \mathrm{Ar} /{ }^{39} \mathrm{Ar}$ Analytical Data for Incremental Heating Experiments on Amphibole Concentrates From Calc-Silicate Horizons Within the Goldenville Formation, Southwestern Meguma Terrane.

\begin{tabular}{cccccccc}
\hline $\begin{array}{l}\text { Release } \\
\text { temp }\left({ }^{\circ} \mathrm{C}\right)\end{array}$ & $\left({ }^{40} \mathrm{Ar} /{ }^{39} \mathrm{Ar}\right)^{*}$ & $\left({ }^{36} \mathrm{Ar} /{ }^{39} \mathrm{Ar}\right)^{*}$ & $\left({ }^{37} \mathrm{Ar} /{ }^{39} \mathrm{Ar}\right)^{\mathrm{c}}$ & $\begin{array}{c}{ }^{39} \mathrm{Ar} \\
\% \text { of total }\end{array}$ & $\begin{array}{c}\%^{40} \mathrm{Ar} \\
\text { non-atmos. }\end{array}$ & $\begin{array}{c}36 \mathrm{Ar} \\
\% \mathrm{Ca}\end{array}$ & $\begin{array}{c}\text { Apparent } \\
\text { Age }(\mathrm{Ma})^{* *}\end{array}$ \\
\hline
\end{tabular}

Sample $1 \mathrm{~A} ; \mathrm{J}=0.008225$

$\begin{array}{rrrrrrrr}550 & 133.84 & 0.36783 & 41.792 & 3.93 & 21.29 & 3.09 & 389.2 \pm 10.6 \\ 625 & 53.61 & 0.10027 & 56.464 & 4.64 & 53.18 & 15.32 & 392.7 \pm 6.4 \\ 700 & 58.33 & 0.11255 & 39.897 & 5.11 & 48.47 & 9.64 & 386.0 \pm 5.5 \\ 750 & 51.59 & 0.08837 & 45.593 & 7.98 & 56.48 & 14.03 & 397.9 \pm 4.2 \\ 775 & 39.76 & 0.04845 & 40.397 & 14.93 & 72.14 & 22.68 & 391.2 \pm 3.1 \\ 785 & 41.78 & 0.05330 & 34.211 & 8.64 & 68.87 & 17.46 & 390.8 \pm 3.9 \\ 800 & 45.08 & 0.06464 & 31.785 & 5.12 & 63.28 & 13.38 & 387.2 \pm 7.7 \\ 825 & 38.20 & 0.04482 & 25.887 & 6.12 & 70.76 & 15.71 & 367.7 \pm 5.3 \\ 835 & 34.82 & 0.03488 & 27.542 & 7.67 & 76.74 & 21.48 & 364.2 \pm 3.7 \\ 865 & 35.77 & 0.03380 & 41.556 & 16.36 & 81.40 & 33.44 & 396.7 \pm 2.2 \\ 885 & 38.26 & 0.03916 & 41.743 & 9.54 & 78.50 & 28.99 & 407.9 \pm 3.3 \\ 925 & 42.12 & 0.05408 & 52.004 & 7.81 & 71.97 & 26.15 & 413.8 \pm 3.5 \\ \text { Fusion } & 96.06 & 0.23355 & 48.619 & 2.15 & 32.22 & 5.66 & 420.7 \pm 21.8 \\ & & & & & & & \\ \text { Total } & 46.57 & 0.07100 & 40.137 & 100.00 & 67.59 & 21.03 & 392.6 \pm 4.5\end{array}$

Sample 2A; $\mathrm{J}=0.008375$

\begin{tabular}{|c|c|c|c|c|c|c|c|}
\hline 500 & 91.38 & 0.20519 & 11.781 & 1.96 & 34.67 & 1.56 & $427.4 \pm 8.0$ \\
\hline 550 & 60.54 & 0.11749 & 16.448 & 1.85 & 44.82 & 3.81 & $372.9 \pm 17.1$ \\
\hline 600 & 73.86 & 0.16904 & 22.661 & 2.10 & 34.83 & 3.65 & $356.6 \pm 24.7$ \\
\hline 650 & 51.92 & 0.09551 & 28.483 & 5.29 & 50.04 & 8.11 & $361.0 \pm 10.5$ \\
\hline 700 & 34.82 & 0.03243 & 23.752 & 20.79 & 77.94 & 19.92 & $374.6 \pm 2.3$ \\
\hline 720 & 34.25 & 0.03013 & 22.011 & 12.33 & 79.16 & 19.87 & $373.9 \pm 1.9$ \\
\hline 740 & 34.13 & 0.03176 & 21.793 & 6.33 & 77.62 & 18.67 & $366.0 \pm 5.6$ \\
\hline 755 & 31.83 & 0.02107 & 23.536 & 8.18 & 86.36 & 30.38 & $378.8 \pm 5.4$ \\
\hline 770 & 30.64 & 0.01739 & 22.961 & 11.91 & 89.23 & 35.91 & $376.9 \pm 3.6$ \\
\hline 785 & 32.88 & 0.02327 & 22.878 & 9.80 & 84.66 & 26.74 & $383.1 \pm 2.3$ \\
\hline 800 & 42.01 & 0.05418 & 22.190 & 5.90 & 66.12 & 11.14 & $382.2 \pm 6.2$ \\
\hline 815 & 42.78 & 0.05373 & 22.196 & 5.33 & 67.04 & 11.24 & $393.4 \pm 3.5$ \\
\hline 830 & 54.16 & 0.08548 & 21.637 & 3.06 & 56.57 & 6.89 & $417.2 \pm 15.5$ \\
\hline 850 & 57.31 & 0.11344 & 22.681 & 2.10 & 44.67 & 5.44 & $355.1 \pm 23.5$ \\
\hline 870 & 53.52 & 0.09871 & 22.237 & 1.63 & 48.83 & 6.13 & $361.7 \pm 13.7$ \\
\hline Fusion & 631.70 & 1.96877 & 22.790 & 1.45 & 8.19 & 0.31 & $657.5 \pm 81.5$ \\
\hline Total & 47.96 & 0.07456 & 22.773 & 100.00 & 72.80 & 19.45 & $381.6 \pm 6.6$ \\
\hline \multicolumn{8}{|c|}{ Sample $3 \mathrm{~A} ; \mathrm{J}=0.007322$} \\
\hline 500 & 172.34 & 0.22589 & 12.904 & 0.67 & 61.87 & 1.55 & $1047.4 \pm 30.9$ \\
\hline 550 & 106.96 & 0.22034 & 16.178 & 0.55 & 40.34 & 2.00 & $499.7 \pm 70.9$ \\
\hline 600 & 94.65 & 0.26071 & 8.363 & 0.54 & 19.31 & 0.87 & $227.7 \pm 72.6$ \\
\hline 650 & 110.97 & 0.28123 & 12.703 & 1.40 & 26.03 & 1.23 & $348.7 \pm 23.8$ \\
\hline 700 & 39.46 & 0.02921 & 13.386 & 6.25 & 80.84 & 12.46 & $381.6 \pm 5.3$ \\
\hline 720 & 35.23 & 0.01664 & 10.706 & 11.82 & 88.47 & 17.50 & $373.1 \pm 3.3$ \\
\hline 740 & 34.84 & 0.01680 & 10.303 & 14.56 & 88.11 & 16.68 & $367.9 \pm 2.3$ \\
\hline 760 & 33.01 & 0.01158 & 10.329 & 9.55 & 92.13 & 24.26 & $364.9 \pm 5.8$ \\
\hline 780 & 31.99 & 0.00914 & 9.792 & 10.48 & 94.00 & 29.15 & $361.0 \pm 1.9$ \\
\hline 800 & 33.15 & 0.01007 & 9.634 & 7.79 & 93.34 & 26.02 & $370.4 \pm 4.2$ \\
\hline 820 & 32.51 & 0.00595 & 9.621 & 17.96 & 96.95 & 43.96 & $376.6 \pm 2.0$ \\
\hline
\end{tabular}


Table 2. ${ }^{40} \mathrm{Ar} /{ }^{39} \mathrm{Ar}$ Analytical Data for Incremental Heating Experiments on Amphibole Concentrates From Calc-Silicate Horizons Within the Goldenville Formation, Southwestern Meguma Terrane.

\begin{tabular}{rccccrrr}
\hline $\begin{array}{c}\text { Release } \\
\text { temp }\left({ }^{\circ} \mathrm{C}\right)\end{array}$ & $\left({ }^{40} \mathrm{Ar} /{ }^{39} \mathrm{Ar}\right)^{*}$ & $\left({ }^{36} \mathrm{Ar} /{ }^{39} \mathrm{Ar}\right)^{*}$ & $\left(^{37} \mathrm{Ar} /{ }^{39} \mathrm{Ar}\right)^{\mathrm{c}}$ & $\begin{array}{c}{ }^{39} \mathrm{Ar} \\
\% \text { of total }\end{array}$ & $\begin{array}{c}\%^{40} \mathrm{Ar} \\
\text { non-atmos. }{ }^{+}\end{array}$ & $\begin{array}{r}{ }^{36} \mathrm{Ar} \\
\% \mathrm{Ca}\end{array}$ & $\begin{array}{c}\text { Apparent } \\
\text { Age }(\mathrm{Ma})^{* *}\end{array}$ \\
\hline 845 & 32.86 & 0.00685 & 9.985 & 15.81 & 96.26 & 39.62 & $377.9 \pm 1.9$ \\
865 & 46.16 & 0.05103 & 9.782 & 0.87 & 69.02 & 5.21 & $380.4 \pm 26.8$ \\
890 & 64.92 & 0.11974 & 9.562 & 0.55 & 46.67 & 2.17 & $363.5 \pm 28.7$ \\
Fusion & 188.51 & 0.52375 & 9.613 & 1.19 & 18.31 & 0.50 & $408.6 \pm 34.3$ \\
Total & 38.64 & 0.02667 & 10.323 & 100.00 & 89.07 & 26.94 & $376.5 \pm 5.2$ \\
\hline
\end{tabular}

*measured

$\mathrm{c}_{\text {corrected for post-irradiation decay of }}{ }^{37} \mathrm{Ar}$ (35.1 day half-life).

$+\left[{ }^{40}\right.$ Artot. - $\left({ }^{36}\right.$ Aratmos. $\left.)(295.5)\right] /{ }^{40}$ Artot.

** calculated using correction factors of Dalrymple et al. (1981); two sigma, intralaboratory errors.

Table 3. ${ }^{40} \mathrm{Ar} /{ }^{39} \mathrm{Ar}$ Analytical Data for Incremental Heating Experiments on Muscovite and Biotite Concentrates from Schist Within the Goldenville Formation, Southwestern Meguma Terrane.

\begin{tabular}{|c|c|c|c|c|c|}
\hline $\begin{array}{c}\text { Release } \\
\text { temp }\left({ }^{\circ} \mathrm{C}\right)\end{array}$ & $\left({ }^{40} \mathrm{Ar} /{ }^{39} \mathrm{Ar}\right)^{*}$ & $\left({ }^{36} \mathrm{Ar} /{ }^{39} \mathrm{Ar}\right)^{*}$ & $\begin{array}{c}{ }^{39} \mathrm{Ar} \\
\% \text { of total }\end{array}$ & $\begin{array}{c}\%^{40} \mathrm{Ar} \\
\text { non-atmos. }\end{array}$ & $\begin{array}{l}\text { Apparent } \\
\text { Age }(\mathrm{Ma})^{* *}\end{array}$ \\
\hline
\end{tabular}

$\underline{\text { Muscovite }}$

Sample 3B; $\mathrm{J}=0.007837$

$\begin{array}{rrrrr}490 & 29.57 & 0.02538 & 1.35 & 74.62 \\ 525 & 24.67 & 0.00521 & 3.65 & 93.73 \\ 575 & 25.27 & 0.00512 & 10.06 & 93.98 \\ 610 & 24.93 & 0.00373 & 25.90 & 95.56 \\ 640 & 24.84 & 0.00323 & 7.92 & 96.13 \\ 710 & 25.26 & 0.00436 & 10.42 & 94.88 \\ 775 & 24.79 & 0.00253 & 34.18 & 96.96 \\ \text { Fusion } & 27.60 & 0.01091 & 6.52 & 88.29 \\ & & & & \\ \text { Total } & 25.17 & 0.00430 & 100.00 & 95.03\end{array}$

$287.7 \pm 9.5$

$93.73 \quad 300.5 \pm 3.1$

$93.98 \quad 307.9 \pm 1.3$

$95.56 \quad 308.8 \pm 0.7$

$96.13 \quad 309.5 \pm 1.0$

$96.96 \quad 311.4 \pm 0.7$

$315.3 \pm 2.3$

$95.03 \quad 309.6 \pm 1.1$

Total without $490,525^{\circ} \mathrm{C}$ and fusion

88.48

$309.9 \pm 0.8$

Sample 2B; $\mathrm{J}=\mathbf{0 . 0 0 8 5 7 2}$

\begin{tabular}{|c|c|c|c|c|c|}
\hline 480 & 27.86 & 0.01815 & 1.76 & 80.73 & $317.9 \pm 4.9$ \\
\hline 510 & 25.55 & 0.00335 & 8.95 & 96.10 & $344.6 \pm 1.1$ \\
\hline 540 & 25.23 & 0.00183 & 42.54 & 97.83 & $346.2 \pm 0.6$ \\
\hline 580 & 25.25 & 0.00177 & 12.27 & 97.91 & $346.6 \pm 0.9$ \\
\hline 630 & 25.41 & 0.00246 & 6.72 & 97.11 & $346.1 \pm 1.9$ \\
\hline 690 & 25.42 & 0.00215 & 8.16 & 97.49 & $347.4 \pm 1.8$ \\
\hline 740 . & 25.35 & 0.00145 & 16.68 & 98.28 & $349.1 \pm 1.0$ \\
\hline usion & 35.94 & 0.03381 & 2.91 & 72.18 & $362.1 \pm 4.2$ \\
\hline Total & 25.67 & 0.00318 & 100.00 & 96.64 & $346.6 \pm 1.1$ \\
\hline al $\mathrm{s}$ & sion & & 95.33 & & $346.6 \pm 0.9$ \\
\hline
\end{tabular}

Total without $480^{\circ} \mathrm{C}$ and fusion 
Table 3. ${ }^{40} \mathrm{Ar} /{ }^{39} \mathrm{Ar}$ Analytical Data for Incremental Heating Experiments on Muscovite and Biotite Concentrates from Schist Within the Goldenville Formation, Southwestern Meguma Terrane.

\begin{tabular}{|c|c|c|c|c|c|}
\hline $\begin{array}{c}\text { Release } \\
\text { temp }\left({ }^{\circ} \mathrm{C}\right)\end{array}$ & $\left({ }^{40} \mathrm{Ar} /{ }^{39} \mathrm{Ar}\right)^{*}$ & $\left({ }^{36} \mathrm{Ar} /{ }^{39} \mathrm{Ar}\right)^{*}$ & $\begin{array}{c}{ }^{39} \mathrm{Ar} \\
\% \text { of total }\end{array}$ & $\begin{array}{c}\%^{40} \mathrm{Ar} \\
\text { non-atmos. }\end{array}$ & $\begin{array}{l}\text { Apparent } \\
\text { Age }(\mathrm{Ma})^{* *}\end{array}$ \\
\hline
\end{tabular}

Biotite

Sample 3B; $\mathrm{J}=0.007961$

\begin{tabular}{rrrrrr}
475 & 24.46 & 0.01542 & 6.46 & 81.35 & $265.2 \pm 1.6$ \\
500 & 21.98 & 0.00182 & 22.42 & 97.52 & $284.2 \pm 0.4$ \\
525 & 21.86 & 0.00124 & 16.22 & 98.30 & $284.9 \pm 0.8$ \\
600 & 23.71 & 0.00708 & 8.82 & 91.14 & $286.3 \pm 1.3$ \\
675 & 22.36 & 0.00284 & 12.46 & 96.23 & $285.2 \pm 0.9$ \\
750 & 22.07 & 0.00179 & 23.14 & 97.58 & $285.5 \pm 0.6$ \\
825 & 24.44 & 0.00885 & 8.93 & 89.27 & $288.9 \pm 1.3$ \\
Fusion & 94.14 & 0.23772 & 1.55 & 25.37 & $314.0 \pm 6.6$ \\
& & & & & $284.5 \pm 0.8$ \\
Total & 23.68 & 0.00747 & 100.00 & 94.04 & $285.4 \pm 0.7$ \\
\multicolumn{2}{l}{ Total without $475^{\circ} \mathrm{C}$ and fusion } & & 91.99 & & \\
\hline
\end{tabular}

${ }^{*}$ measured
$+\left[{ }^{40} \mathrm{Ar}\right.$ tot. $-\left({ }^{36} \mathrm{Ar}\right.$ atmos. $\left.)(295.5)\right] /{ }^{40} \mathrm{Ar}$ tot.
${ }^{* *}$ calculated using correction factors of Dalrymple et al. (1981); ${ }^{37} \mathrm{Ar} /{ }^{39} \mathrm{Ar}$ corrected ratios $<0.02$ in
all analyses; two sigma, intralaboratory errors.
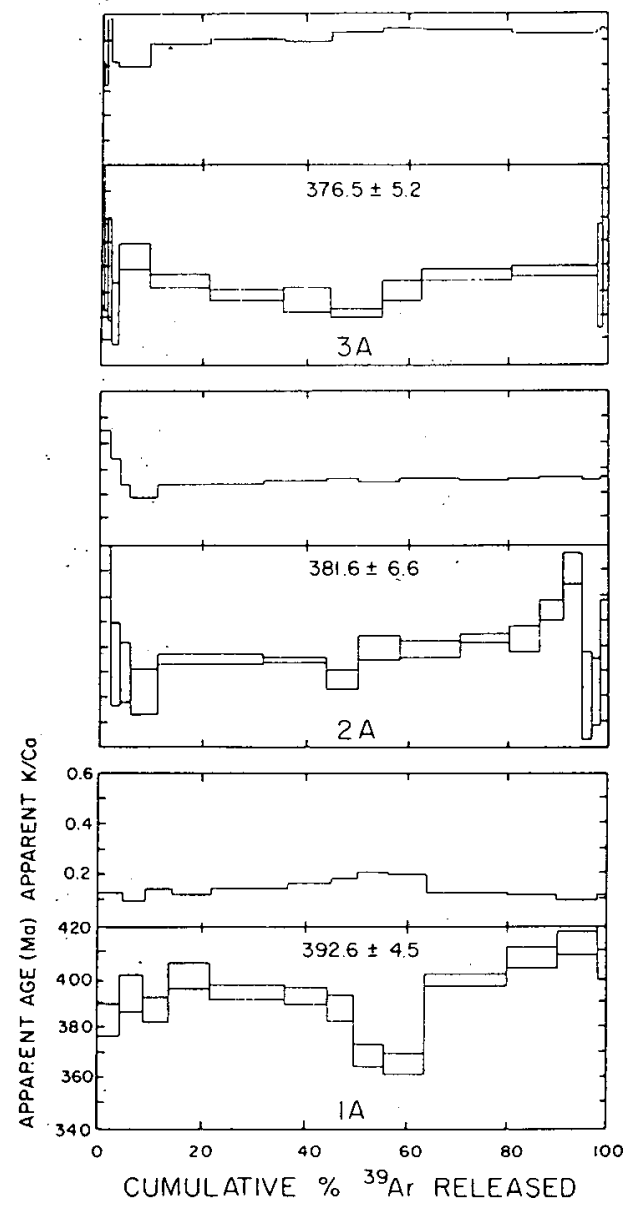

Fig. 3. ${ }^{40} \mathrm{Ar} \beta 9 \mathrm{Ar}$ incremental-release age spectra of amphibole from calc-silicate in the southwestem Meguma Terrane, Nova Scotia. Data plotted as in Figure 2. All spectra have similar abscissa and ordinate coordinates. Total-gas ages listed on each spectra.

\section{GEOLOGIC SIGNIFICANCE}

Amphibole, muscovite, and biotite at location 1 immediately north of the Shelburne pluton record post-metamorphic cooling ages of $385.1 \pm 2.6 \mathrm{Ma}, 346.9 \pm 0.9 \mathrm{Ma}$ and $341.1 \pm 0.9 \mathrm{Ma}$. Generally similar mica ages were reported by Dallmeyer and Keppie (1987) for other locations within the andalusite-staurolite-cordierite zone north of the Shelburne pluton. These likely date diachronous cooling following a contact thermal overprint associated with emplacement of the two plutons at $c a .370-375$ Ma. Relative variations in the cooling ages suggest that the amphibole composition examined in this study has a higher closure temperature than muscovite, and may therefore approximate the ca. $500^{\circ} \mathrm{C}$ value suggested by Harrison (1981) for homblende. The biotite and muscovite spectra are internally concordant and provide no record for a later thermal disturbance of intracrystalline argon systems.

Amphibole and muscovite south of the Port Mouton pluton (location 2) record post-metamorphic cooling ages of 369.1 \pm 2.9 $\mathrm{Ma}$ and 346.9 $0.9 \mathrm{Ma}$. These are interpreted to date diachronous cooling through appropriate argon retention temperatures following emplacement of the Port Mouton pluton. Amphibole, muscovite and biotite south of the Barrington Passage pluton (location 3) record cooling ages of $366.9 \pm 5.6 \mathrm{Ma}, 309.9 \pm 0.8 \mathrm{Ma}$, and $285 \pm 0.7 \mathrm{Ma}$. The amphibole age probably dates cooling following a thermal overprint associated with the intrusion of the Barrington Passage pluton; however, the $c a .310$ Ma plateau age recorded by coexisting muscovite is similar to plateau ages recorded by Dallmeyer and Keppie (1987) for muscovite and biotite north of Sable Island. The ages are inferred to date cooling following reheating adjacent to an unexposed pluton of approximately the same age as the $c a .315 \mathrm{Ma}$ Wedgeport pluton. The ca. 285 Ma plateau age of the coexisting biotite could be inter- 

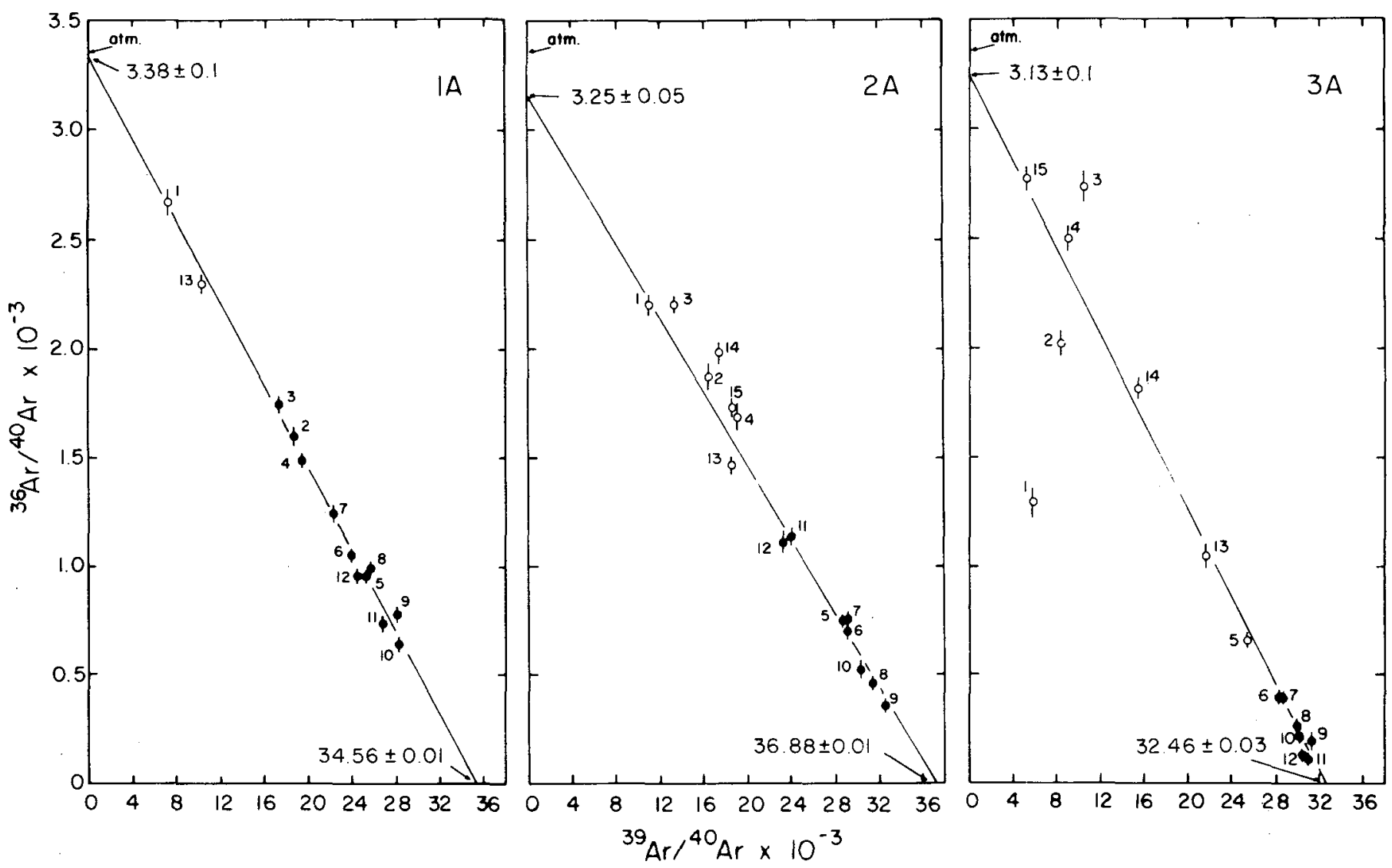

Fig. 4. ${ }^{36} \mathrm{Ar}{ }^{\mu 0} \mathrm{Ar}$ vs. ${ }^{39} \mathrm{Ar}{ }^{\mu 0} \mathrm{Ar}$ isotope correlation diagrams for amphibole from calc-silicate horizons in the southwestern Meguma Terrane, Nova Scotia: atm. $=$ ratio in present-day atmosphere.

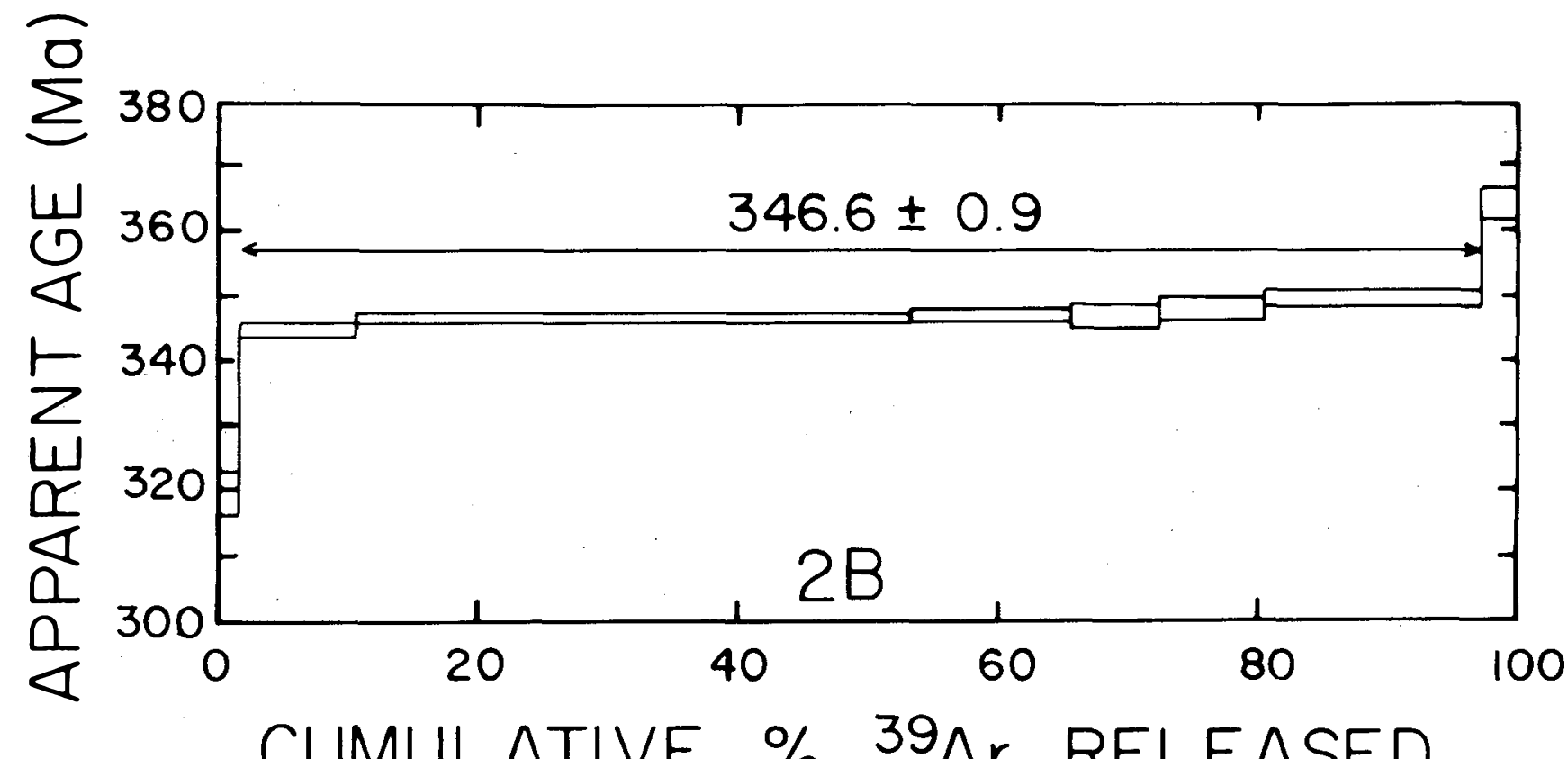

Fig. 5. ${ }^{40} \mathrm{Ar} \beta{ }^{9} \mathrm{Ar}$ incremental-release age spectrum of muscovite from schist interbedded with calc-silicate at location 2. Data plotted as in Figure 2. Plateau age is listed. 


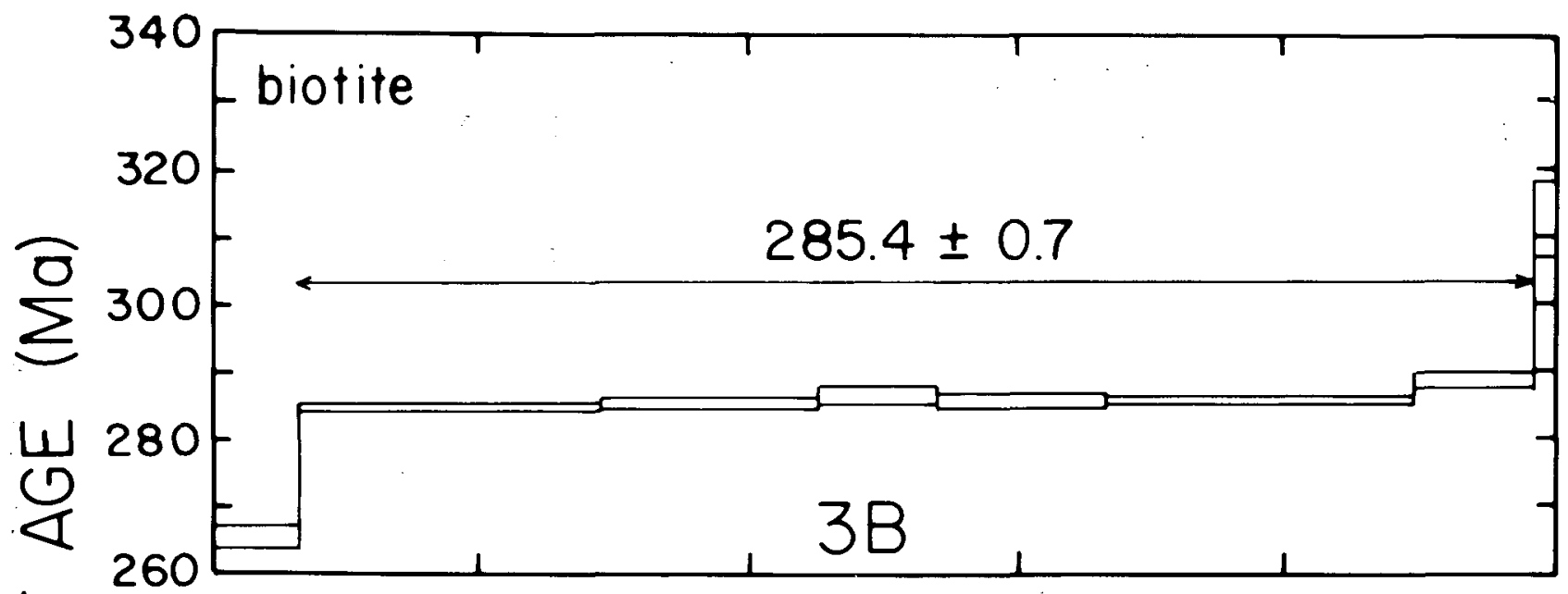

桌

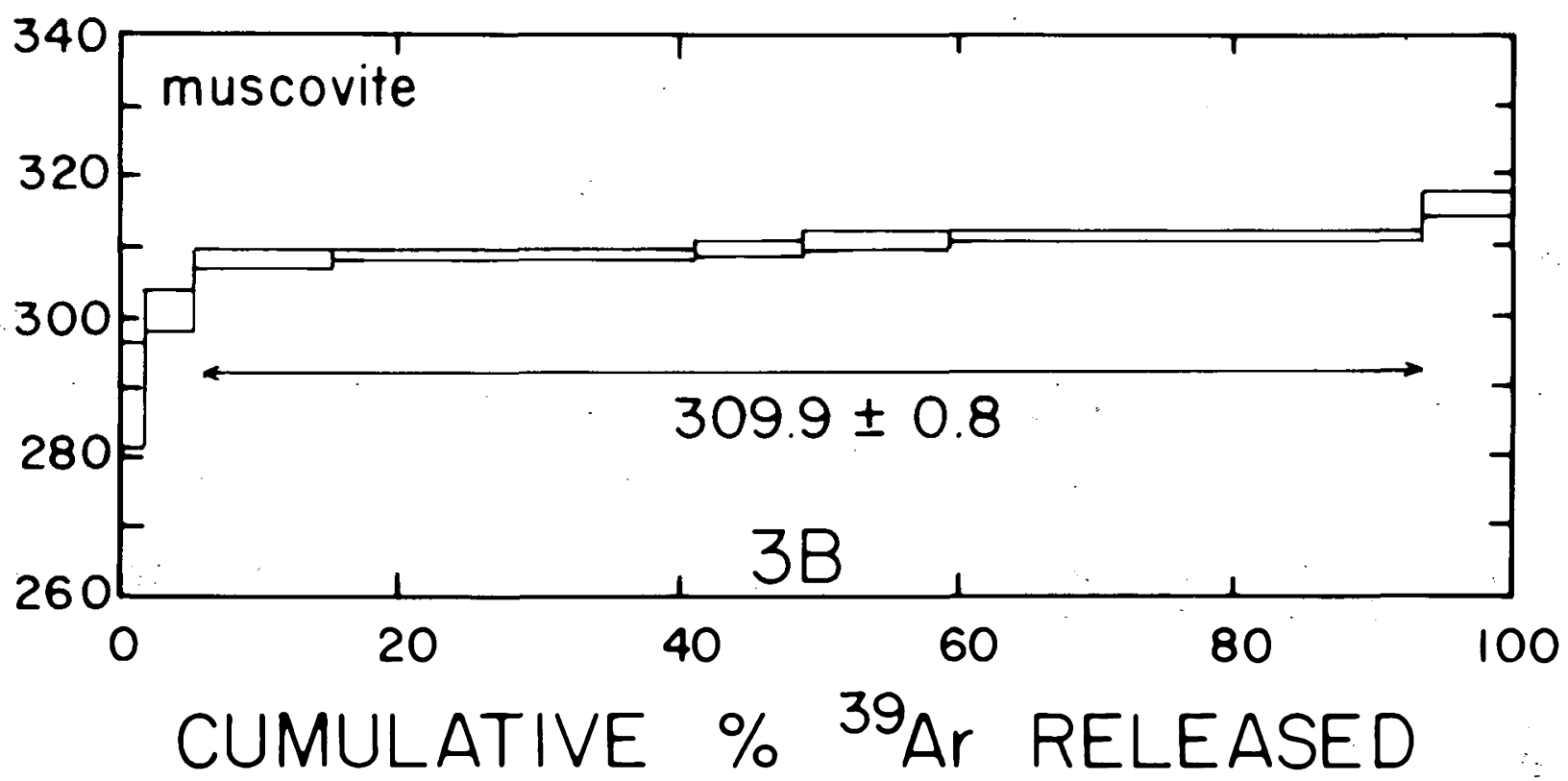

Fig. 6. ${ }^{40} \mathrm{Ar} /{ }^{\beta} \mathrm{Ar}$ incremental-release age spectra of muscovite and biotite from schist interbedded with calc-silicate at location 3 . Data plotted as in Figure 2. Plateau ages are listed.

preted to date either slow cooling through the biotite blocking temperature following the $c a .315$ ma thermal event of a complete rejuvenation following a younger thermal event. The latter alternative finds support in: (1) the previously reported muscovite plateau age of $c a .287 \mathrm{Ma}$ recorded in southem Cape Sable Island (Dallmeyer and Keppie, 1987); and (2) the low-temperature spectrum discordance in the muscovite at location 3 and at other adjacent locations, which are consistent with slight volume-diffusive loss of argon during a low grade, ca. $290 \mathrm{Ma}$ thermal event. Collectively these data at location 3 suggest that: (1) contact metamorphic temperatures during the ca. $315 \mathrm{Ma}$ event exceeded those required to totally reset muscovite and biotite but remained below those required to reset amphibole (i.e., between ca. 500-400 oC); and (2) during the ca. $290 \mathrm{Ma}$ event, contact metamorphic temperatures were sufficient to totally rejuvenate biotite but remained below those required to totally reset muscovite (i.e., between $\mathrm{ca} .350-325^{\circ} \mathrm{C}$ ).

\section{CONCLUSIONS}

Extensive contact aureoles appear to have developed during emplacement of the Port Mouton, Shelburne and Barrington Passage plutons at ca. 370-375 Ma. This thermal overprint completely rejuvenated intracrystalline argon systems within all minerals which had grown during an earlier (ca.400-410 Ma) M regional metamorphism. Post-metamorphic cooling through calc-silicate amphibole closure temperatures $\left(\mathrm{ca} .500^{\circ} \mathrm{C}\right.$ ?) occurred shortly after pluton emplacement. Cooling through the lower temperatures required for intracrystalline retention of argon within muscovite and biotite occurred between 340 and $350 \mathrm{Ma}$.

Southern portions of the contact metamorphic aureoles of the Shelburne and Barrington Passage plutons were affected by later reheating associated with emplacement of plutons at $c a .315$ and $290 \mathrm{Ma}$. Argon systems within muscovite and biotite were 
variably rejuvenated during these events, but were not reset in hornblende. Therefore, the amphibolite facies metamorphism recorded in southwestern portions of the Meguma Terrane appears to largely reflect the results of an $c a .370 \mathrm{Ma}$ contact thermal event.

\section{ACKNOWLEDGEMENTS}

Funds for this project were provided by the Nova Scotia Provincial Government as part of a joint Federal-Provincial Mineral development Agreement 1984-89. The Director of the Mineral Resources Division of the Nova Scotia Department of Mines and Energy has authorized publication. This paper represents a contribution of I.G.C.P. Project 233, "Terranes in the Circum-Atlantic Paleozoic Orogens." Mr. J. L. Cho and the Department of Geology, Yonsei University, Seoul, Korea, are thanked for their assistance during microprobe analysis.

ALEXANDER, E.C., JR., MICHELSON, G.M., and LANPHERE, M.A. 1978. MMhb-1: A new ${ }^{40} \mathrm{Ar} \beta{ }^{9} \mathrm{Ar}$ dating standard. In Short papers of the Fourth Intemational Conference, Geochronology, Cosmochronology, isotope Geology. Edited by R.E. Zartman. United States Geological Survey, Open File Report 78-701, pp. 68.

BORQUE, A.D. 1985. Migmatization and metamorphism associated with the Barrington Passage Pluton. Shelburne and Yarmouth Counties, Nova Scotia. B.Sc. Honours thesis, Acadia University, Wolfville, Nova Scotia.

CHO, D.L. 1985. Petrography and Rb.Sr ages of the Imgye Granite in northeastern Ockcheon Belt, Korea. Unpublished Ms. thesis, Yonsei University.

DALLNiEYER, R.D. and KEPPIE, J.D. 1987. Polyphase late Paleozoic tectonothermal evolution of the southwestern Meguma Terrane, Nova Scotia: Evidence from ${ }^{40} \mathrm{Ar} \beta{ }^{\beta}$. Ar mineral ages. Canadian Journal of Earth Sciences, 24, pp. 1242-1254.

DALR YMPLE, G.B., ALEXANDER, E.C., LANPHERE, M.A., and KRAKER, G.P. 1981. Ir adiation of samples for ${ }^{40} \mathrm{Ar} /{ }^{\beta 9} \mathrm{Ar}$ dating using the Geological Survey TRIGA reactor. United States Geological Survey Professional Paper 1176, 55 p.

DODSON, M.H. 1973. Closure temperature in cooling geochronological and petrological systems. Contributions to Mineralogy and Petrology, 40, pp. 259-274.

HARRISON, T.M. 1981. Diffusion of ${ }^{40} \mathrm{Ar}$ in homblende. Contributions to Mineralogy and Petrology, 78, pp. 324-331.

HARRISON, T.M., DUNCAN, I., and MCDOUGALL, I. 1985. Diffusion of ${ }^{40} \mathrm{Ar}$ in biotite: Temperature, pressure and compositional effects. Geochimica et Cosmochimica Acta, 49, pp. 2461-2468.

HAWTHORNE, F.C. 1982. Crystal chemistry of the amphiboles. In Amphiboles and other hydrous pyriboles Mineralogy. Edited by D.R. Veblen. Reviews in Mineralogy, 9a, Mineralogical Society of America, pp. 1-9.

JÄGER, E. 1979. Introduction to geochronology. In Lectures in isotope geology. Edited by E. Jäger and J.C. Hunziker. Berlin, Springer-Verlag, pp. 1-12.

KEPPIE, J.D. 1976. Structural model for the saddle reef and associated gold veins in the Meguma Group, Nova Scotia. Nova Scotia Department of Mines, Paper 76-1, $34 \mathrm{p}$.

KEPPIE,J.D.,CURRIE, K., MURPHY, J.B.,PICKERILL, R.K., FYFFE,
L.R., and ST. JULIEN, P. 1985. Appalachian geotraverse (Canadian Mainland). Geological Association of Canada Excursion 1, $181 \mathrm{p}$.

KEPPIE, J.D. and MUECKE, G.K. 1979. Metamorphic map of Nova Scotia. Nova Scotia Department of Mines and Energy. Scale $1: 1,000,000$.

KEPPIE, J.D. and KROGH, T. 1988. (In press.) U-Pb crystallization ages for zircon and monazite within granitic plutons from the southwestem Meguma Terrane, Nova Scotia. Bulletin of the Geological Society of America.

KEPPIE, J.D., ODOM, L., and CORMIER, R.F. 1983. Tectonothermal evolution of the Meguma Terrane: radiometric controls. Geological Society of America, Abstracts With Programs, 1983, 15, p. 136.

LEAKE, B. 1978. Nomenclature of amphiboles. Canadian Mineralogist, 16, pp. 501-520.

MISNER, A.R. 1986. Metamorphism of the northem part of the Shelburne Metamorphic Complex, Shelburne and Yarmouth Counties, Nova Scotia. B.Sc. Honours thesis, Acadia University, Wolfville, Nova Scotia.

RADICATI DI BROZOLO, F., HUNEKE, J.C., PAPANSTASSIOU, D.A., and WASSERBURG, J. 1981. ${ }^{40} \mathrm{Ar} /{ }^{39} \mathrm{Ar}$ and Rb-Sr age determinations on Quatemary volcanic rocks. Earth and Planetary Science Letters, 53, pp. 233-244.

RAESIDE, R.P., WHITE, C.E., and WENTZELL, B.D. 1985. The metamorphic development of the Shelburne Complex, southwest Nova Scotia. Geological Association of Canada, Program with Abstracts, 10, p. A50.

ROBBINS, G.A. 1972. Radiogenic argon diffusion of muscovite under hydrothermal conditions. M.Sc. thesis, Brown University, Providence, Rhode Island.

RODDICK, J.C. 1978. The application of isochron diagrams in ${ }^{40} \mathrm{Ar} /$ ${ }^{39} \mathrm{Ar}$ dating: A discussion. Earth and Planetary Science Letters, 41, pp. 233-244.

RODDICK, J.C., CLIFF, R.A., and REX, D.C. 1980. The evolution of excess argon in alpine biotite $-{ }^{40} \mathrm{Ar} \beta 9 \mathrm{Ar}$ analysis. Earth and Planetary Science Letters, 48, pp. 185-208.

ROSS, D.M. 1985. Structure and metamorphism of the Pubnico area, Yarmouth County, Nova Scotia. B.Sc. Honours thesis, Acadia University, Wolfville, Nova Scotia.

SAGE, J.D. 1984. Variable water pressure metamorphic assemblages in the Meguma Group, Nova Scotia. M.Sc. thesis, Virginia Polytechnic Institute and State University, Blacksburg, Virginia.

STEIGER, R.H. and JÄGER, E. 1977. Subcommission on geochronology: convention on the use of decay constants in geo- and cosmochronology. Earth and Planetary Sciences, 36, pp. 359-362.

TAYLOR, F.C. and SCHILLER, E.A. 1966. Metamorphism of the Meguma Group of Nova Scotia. Canadian Journal of Earth Sciences, 3, pp. 959-974.

WAGNER, G.A., REIMER, G.M., and JÄGER, E. 1977. Cooling ages derived from apatite fission, mica $\mathrm{Rb}$-Sr and $\mathrm{K}$-Ar dating: the uplift and cooling history of the central Alps. Padovia University Institute of Geology Mineral Memoir, 30, pp. 1-27.

WENTZELL, B.D. 1985. The transition from staurolite to sillimanite zone, Port LaTour, Nova Scotia. B.Sc. Honours thesis, Acadia University, Wolfville, Nova Scotia.

WHITE, C.E. 1984. Structure and metamorphism of the Jordon River Valley. Shelburne County, Nova Scotia. B.Sc. Honours thesis, Acadia University, Wolfville, Nova Scotia.

YORK, D. 1969. Least squares fitting of a straight line with correlated errors. Earth and Planetary Science Letters, 5, pp. 320-324. 